ЕФЕКТИВНІСТЬ НЕТРАДИЦІЙНИХ МЕТОДИК ЯК СКЛАДНИКА ЗДОРОВ'ЯЗБЕРЕЖУВАЛЬНИХ ТЕХНОЛОГІЙ У ГАСТРОЕНТЕРОЛОГІЇ

\title{
EFFECTIVENESS OF UNORTHODOX METHODS AS A COMPONENT OF HEALTH SAVING TECHNOLOGIES IN GASTROENTEROLOGY
}

Стаття присвячена одній з актуальних
проблем - підвищенню ефективності вико-
ристання методик здоров'язбереження для
хворих на виразкову хворобу шлунка та два-
надиятипалої кишки, хронічний холецистит.
Зокрема, розкриваються сутність і необхід-
ність самоорганізованої діяльності пацієн-
тів для покращення стану здоров'я.
Основна увага зосереджується на струк-
турних компонентах (організаційний, кому-
нікативний) програми оздоровлення для
хворих на виразкову хворобу шлунка та два-
надиятипалої кишки, хронічний холецистит.
Спільній роботі науковців, лікарів практичної
медицини, пацієнтів. Обстеження проводилось серед 54 хворих працездатного віку. Усі хворі перебували у фразі неповної ремісії захворювання, пройшли співбесіду і погодились на обстеження, 3 наступним виконанням запропонованих їм практичних рекомендацій. Для вирішення поставлених завдань були проведені стандартні обстеження (виявлення основних скарг, збір анамнезу хвороби, анамнезу життя; встановлення головних клінічних показників хвороби, специфрічних клінічних симптомів; вивчення лабораторних, фрункціональних, інструментальних показників).

Під час надходження всі хворі на виразкову хворобу шлунка та дванадцятипалої кишки за важкістю та перебігом хвороби, тобто комплексом клінічних, лабораторних, фуункціональних показників, були приблизно однаковими. Скаржились на періодичну, помірно виражену (невиразного характеру) болючість у зонах, характерних для основного захворювання.

Комплекс оздоровлення передбачав дієтотерапію, фрітотерапію, лікувальну фозичну культуру. Наприкінці курсу оздоровлення зазначено значні позитивні зміни суб'єктивних і об'єктивних показників у 27 (87\%) хворих на виразкову хворобу шлунка та дванадиятипалої кишки, 13 (86\%) хворих на хронічний холецистит. Помірне покращення загального стану та самопочуття загалом спостерігалося в шести пацієнтів (неповне виконання рекомендацій у звя'зку з ненормованим робочим днем, робота в нічні зміни, періодичні стресові ситуаціі).

Ключові слова: виразкова хвороба шлунка та дванадиятипалої кишки, хронічний холе- цистит, нетрадиційні методи оздоровлення, інноваційна діяльність медичних працівників, здоров'язбережувальна діяльність пацієнта.

The article deals with one of the urgent problems - increasing the efficiency of using the methods of health preservation for patients with gastric ulcer (GU), duodenal ulcer (DU), and chronic cholecystitis (CC). In particular, the essence and necessity of patients' self-organizing activities to improve their health is revealed. The main focus is placed on the structural components (organisational, communicative) of a wellness programme for patients, joint work of scientists, practitioners, patients.

The research was conducted on 54 patients of the employable age. All patients were in the phase of incomplete remission of the disease, were interviewed and agreed to be examined, with the subsequent implementation of practical recommendations they were offered. In order to solve the established objectives, standard examinations were carried out (identification of the main complaints, analysis of antecedent anamnesis, anamnesis vitae, determining the main clinical indicators of the disease, specific clinical symptoms, study of lab test values, functional, instrumental indicators).

At admission, all patients with gastric (GU) and duodenal ulcer (DU) were approximately equal in severity and course of the disease, i.e., complex clinical, laboratory, functional indicators. They complained of periodic, moderate (inexpressive) morbidity in the areas characteristic of the main disease.

The recuperation complex included diet therapy, phytotherapy and therapeutic physical training. At the end of the recuperation course there were significant positive changes in subjective and objective indicators in 27 (87\%) patients with $G U$ and DU, and 13 (86\%) patients with CC. Moderate improvement in general condition and well-being was observed in only six patients (explained by incomplete implementation of recommendations due to irregular working hours, work during night shifts, periodic stressful situations).

Key words: gastric and duodenal ulcer, chronic cholecystitis, unconventional methods of recuperation, medical workers' innovative activity, patient's health preserving activity.

Ужгородської міської ради

Постановка проблеми в загальному вигляді. Робота присвячена одній 3 актуальних проблем покращенню стану здоров'я хворих, що страждають від хронічної соматичної патології. Збільшення серед працездатного населення захворюваності за такими патологіями, як виразкова хвороба шлунка (далі - ВХШ), виразкова хвороба дванадцятипалої кишки (далі - ВХДК), хронічний холецистит (далі - XX) значною мірою призводить до негативних соціальних і економічних наслідків.

Процес ульцероутворення за ВХШ та ВХДК, як і зміни запального та незапального характеру в разі $\mathrm{XX}$, неможливо пояснити тільки з позицій дисбалансу між чинниками агресії та захисту, що взаємодіють на місцевому рівні. Сучасні концепції патогенезу розглядають ці патології як системне гастроентерологічне захворювання, основна увага приділяється порушенням адаптивних регуляторних систем на різних рівнях (неврогенні чинники, психоемоційні стреси, патологічні зміни тонусу блукаючого нерва тощо). У процесі хронізації захворювання викривлені імпульси надходять у ЦНС, це негативно відбивається на іїі фрункціональному стані, відношеннях між корою головного мозку та 
перифрерійними органами, процесах керування травленням, психічному статусі хворих, утворюючи, таким чином, замкнуте коло [1, с. 391-407].

Використання сучасних методик здоров'язбереження різних груп населення відповідає і основним принципам відновлення стану здоров'я хворих із захворюваннями шлунково-кишкового тракту (далі - ШКТ): закінчення медикаментозного етапу лікування, найшвидше повернення до повноцінної працездатності. Значна роль відводиться сімейним лікарям, вузьким спеціалістам. Накопичений науковцями та лікарями великий досвід використання нетрадиційних, природних і префрормованих фрізичних чинників реалізується на основі призначення комплексів здоров'язбереження (попередження загострень, можливих ускладнень) та здоров'явідновення, залежно від специфічних властивостей і впливу на певні процеси у тканинах організму (патогенетичний принцип); застосування нетрадиційних методів відновлення на якомога більш ранній стадії; тісної взаємодії із хворим (за необхідності, і з родиною) [2, с. 157-160].

Аналіз останніх досліджень і публікацій. За даними світової статистики, 6-10\% дорослого населення розвинених країн хворіють на зазначені хвороби, в Україні стоять на обліку приблизно 5 млн хворих. Ситуація ускладнюється з огляду на те, що, за даними Всесвітньої організації охорони здоров'я (далі - ВОО3), 50\% хворих у підгострий період і період нестабільної ремісії не виконують рекомендації лікарів реабілітаційного та рекреаційного спрямування, із них 70\% роблять це свідомо, 30\% не мають можливості вчасно їх дотримуватися. У 58\% пацієнтів контроль перебігу лікування (реабілітації) з боку обслуговуючого персоналу відсутній [1, с. 391-407; 2, с. 157-160; 3 , с. $56-66 ; 4$, с. 83-92].

Традиційні методи лікування захворювань шкТ ефективні, якщо вони своєчасні, комплексні й індивідуалізовані, пов'язані із функціональним станом шлунка, дванадцятипалої кишки (далі ДК), жовчного міхура (далі - ЖМ) зокрема та шКТ загалом (складник діяльності фрізіологічних систем організму, що забезпечують гомеостаз).

В основі заходів здоров'явідновлення та здоров'язбереження - комплекс медичних і соціально-економічних, психологічних методик та прийомів, спрямованих на збереження та підвищення компенсаторно-адаптаційних здібностей організму, усунення причин і умов, що спричиняють виникнення, загострення або рецидив захворювання, із дотриманням принципу комплексності (наприклад, застосування лікувальної фрізичної культури (далі - ЛФК), фрітотерапії (далі - ФТ), дієтотерапії) для впливу на паталогічний процес [3, с. 56-66; 4, с. 83-92; 5, с. 166-168].

Дієтотерапія (далі - ДТ) посідає одне 3 важливих місць в оздоровленні хворого. Основними її принципами є: захистити слизову від механічних, термічних і хімічних подразнень, забезпечити організм основними харчовими інгредієнтами та вітамінами, позитивно впливати на репаративні процеси, регулювати секреторну і кислотоутворюючу функції шлунка, ДП, моторну фрункцію ЖМ. Речовини різних класів, що містяться в харчових продуктах, беруть активну участь у широкому спекті біохімічних реакцій. Харчова спеціалізація завдяки відкриттям у геноміці дала можливість оптимізувати рекомендації 3 харчування, підвищити еорективність профрілактики та лікування хронічних захворювань.

Під час використання ФТ підтверджені різноманітні метаболічні ефректи на мембранно-клітинному та мікроциркуляторному рівнях (органопротекторна, мембранопротекторна дія), у тонких структурах імунного захисту й обміну речовин, чого позбавлені синтетичні засоби. Фітопрепарати здатні втручатися в тонкі механізми біохімічних і біофізичних процесів, заміняти ушкоджені й активізувати пригнічені ланки метаболічних процесів в організмі, коригувати зміни у складному обмінному механізмі адаптогенних, імунних і нейрогуморальних реакцій.

Фізичні вправи роками використовуються в комплексах відновлення стану здоров'я хворих із патологією внутрішніх органів: для нормализації моторної фрункції шлунка, ДК, ЖМ, кишківника загалом; нормалізації скорочувальної здатності м'язів, збільшення сили діафрагми [3, с. 56-66; 4, с. 83-92; 5, с. 166-168; 6, с. 238-244].

Виділення не вирішених раніше частин загальної проблеми. Підвищення ефективності використання здоров'ябережувальних технологій і комплексів реабілітації для хворих із хронічною патологією ШКТ залежить від низки проблем, що виникають у процесі взаємодії медичного персоналу та пацієнта: лікар не повністю розкриває хворому важливість виконання окремих етапів оздоровлення після виходу з періоду загострення (часто з використанням масованої фрармакотерапії); пацієнт не в повному обсязі виконує рекомендації щодо особливостей приготування їжі, регулювання харчування протягом доби, зміни харчового раціону тощо; у хворого немає можливостей, а іноді й бажання змінити свій спосіб життя (збільшити період фрізичної активності, збирати або купляти лікарські трави та готувати з них оздоровчі чаї).

Мета статті - підвищити ефективність здоро'вязбережувальних технологій для хворих із гастроентерологічною патологією. Завдання дослідження: розробити комплекс нетрадиційних методів відновлення для хворих із гастроентерологічною патологією, що буде включати сумісне та послідовне застосування ЛФК, ДТ і ФТ; вивчити есрективність застосування нового комплексу нетрадиційних методів відновлення. 
Виклад основного матеріалу. Обстеження проводилось у 54 хворих працездатного віку: 19 хворих із ВХШ, 18 хворих із ВХДП, 17 хворих на XX. Усі хворі перебували у фразі неповної ремісії захворювання, пройшли співбесіду і погодились на обстеження, 3 наступним виконанням запропонованих їм практичних рекомендацій. Для вирішення поставлених завдань були проведені стандартні обстеження (виявлення основних скарг, збір анамнезу хвороби, анамнезу життя; встановлення головних клінічних показників хвороби, специфічних клінічних симптомів; вивчення лабораторних, функціональних, інструментальних показників). Статистичну обробку результатів досліджень проводили методом варіаційої статистики із застосуванням стандартного пакету прикладних програм SPSS 13.0 for Windows.

Запропонований пацієнтам ОГ комплекс включав дієтичне харчування (в основному відповідає дієті № 1 за Певзнером), 4-5-разове, за групами, залежно від захворювання, із частковим розширенням переліку продуктів, можливих до вживання хворими (овочі та фррукти) без загрози виникнення больових, диспептичних або психоемоційних порушень. Загальні рекомендації для пацієнтів такі: дотримання (за можливості) раціонального режиму праці та відпочинку (звільнення від нічних змін і відряджень); відмова від шкідливих звичок і запобігання стресовим ситуаціям; працетерапія (роботи на свіжому повітрі - присадибна ділянка, город); фрізична активність. Рекомендації із приготування фрітопрепаратів (настої, відвари), призначення їх у схемі комплексного оздоровлення було пов'язане зі специфічними властивостями трав: знеболюючими, протизапальними, спазмолітичними, обволікаючими, пом'якшуючими, заспокійливими, вітаміновмісними.

У комплекс вправ ЛФК входили вправи переважно для великих і середніх м'язових груп, 3 великим числом повторень (під час м'язової роботи виділяється багато енергії, необхідної для нормального фрункціонування клітин організму, зокрема і для відновлення пошкоджених клітин). Обов'язковими були вправи для черевного преса, дихальні вправи. Основне завдання - дихати правильно, повним диханням, «животом, грудьми та плечима», тобто включати нижнє, серединне та верхнє дихання Пульс у період ЛФК не повинен перевищувати 120-130 поштовхів за хвилину. Заняття ЛФК проводидися не раніше ніж через 2-2,5 години після прийому їжі. На початку курсу основні вихідні положення - лежачи на спині і правому боці, на похилій площині з піднятим на 15-20 см головним кінцем. Критерієм правильності виконання всіх вправ була відсутність у процесі тренування печії або відрижки. У комплекс фрізичних вправ поступово вводили рухи ногами, повороти тулуба у вихідному положенні, лежачи на спині, на правому, потім і на лівому боці, животі, колінах, стоячи (розгинання, нахили тулуба у боки, повороти, присідання, ходьба, біг тюпцем).

Під час надходження усі хворі на ВХШ і ВХДП за важкістю та перебігом хвороби, тобто комплексом клінічних, лабораторних, функціональних показників, були приблизно однаковими. Скаржились на періодичну, помірно виражену (невираз-

Динаміка основних суб'єктивних і об'єктивних проявів у хворих на ВХШ та ВХДП

Таблиця 1 під впливом нетрадиційних методів оздоровлення

\begin{tabular}{|c|c|c|c|c|c|c|}
\hline \multirow{3}{*}{ Показники } & \multirow{2}{*}{\multicolumn{2}{|c|}{ До $n=37$}} & \multicolumn{4}{|c|}{ Після } \\
\hline & & & \multicolumn{2}{|c|}{ Зникли } & \multicolumn{2}{|c|}{ Зменш. } \\
\hline & бc & $\%$ & бс & $\%$ & бс & $\%$ \\
\hline $\begin{array}{l}\text { Помірна періодична болючість тупого, невиразного харак- } \\
\text { теру з локалізацією в епігастральній зоні }\end{array}$ & 31 & 84 & 27 & 87 & 4 & 13 \\
\hline Нудота (періодична) & 20 & 54 & 20 & 100 & - & - \\
\hline Печія, відрижка кислим (періодична) & 37 & 100 & 37 & 100 & - & - \\
\hline Об'єктивна чутливість за пальпації в епігастральній зоні & 31 & 84 & 27 & 87 & 4 & 13 \\
\hline Симптом Менделя (+ +) & 20 & 54 & 16 & 80 & 4 & 20 \\
\hline Симптом Лаенека (+) & 20 & 54 & 20 & 100 & - & - \\
\hline
\end{tabular}

Динаміка основних суб'єктивних і об'єктивних проявів у хворих на XX під впливом нетрадиційних методів оздоровлення

\begin{tabular}{|c|c|c|c|c|c|c|}
\hline \multirow{3}{*}{ Показники } & \multirow{2}{*}{\multicolumn{2}{|c|}{ До $n=17$}} & \multicolumn{4}{|c|}{ Після } \\
\hline & & & \multicolumn{2}{|c|}{ Зникли } & \multicolumn{2}{|c|}{ Зменш. } \\
\hline & абс. & $\%$ & абс. & $\%$ & абс. & $\%$ \\
\hline Болючість у правому підребер'ї ниючого характеру & 15 & 88 & 13 & 86 & 2 & 14 \\
\hline Відчуття гіркоти в ротовій порожнині (періодично), відрижка гірким & 17 & 100 & 17 & 100 & - & - \\
\hline Ознаки кишкової диспепсії (метеоризм, урчання, здуття) & 15 & 88 & 15 & 100 & - & - \\
\hline Пальпаторно - болючість у правому підребер'ї & 17 & 100 & 15 & 88 & 2 & 2 \\
\hline
\end{tabular}


ного характеру) болючість у зонах, характерних для основного захворювання (таблиця 1).

У групі хворих XX 15 (88\%) пацієнтів зазначали помірну болючість у правому підребер'ї ниючого характеру, метеоризм, здуття, урчання по ходу кишківника, усіх хворих (100\%) турбували гіркота в ротовій порожнині; об'єктивно за пальпації фріксувалась помірна болючість у правому підребер'ї (таблиця 2).

Наприкінці курсу оздоровлення зазначено значні позитивні зміни суб'єктивних і об'єктивних показників у 27 (87\%) хворих на ВХШ і ВХДП, $13(86 \%)$ хворих на XX. Помірне покращення загального стану та самопочуття зазначено загалом у шести пацієнтів (неповне виконання рекомендацій у звя'зку з ненормованим робочим днем, робота в нічні зміни, періодичні стресові ситуації).

Висновки. У результаті аналізу матеріалів літературних джерел щодо сучасних розробок стосовно сучасних методик оздоровлення для хворих на ВХШ, ВХДП і ХХ, тісної взаємодії молодого науковця та спеціалістів практичної медицини, з метою підвищення ефективності використання здоро'вязбережувальних технологій для хворих із гастроентерологічною патологією, був розроблений комплекс нетрадиційних методів оздоровлення, що включав сумісне та послідовне застосування ЛФК, дієтотерапії та фрітотерапії. Запропонований комплекс дозволив підвищити загальну ефективність оздоровлення пацієнтів. Іноваційна програма спільної роботи науковців і представників практичної медицини є перспективною, потребує подальшого вивчення та реалізації.

\section{БІБЛІОГРАФІЧНИЙ СПИСОК:}

1. Актуальні питання внутрішніх хвороб у практиці сімейного лікаря : навчальний посібник / Ю. Вороненко та ін. ; за ред. Ю. Вороненка, О. Шекери, Л. Хіміон. Київ: Заславський А.Ю., 2018. С. 397-407.

2. Остапенко С. Здоров'язбережувальні технології як сучасний підхід формування ціннісних орієнтацій особистості. Фізична реабілітація та здоров'язбережувальні технології: реалії $і$ перспективи : матеріали II Всеукраїнської науковопрактичної інтернет-конореренції, 24 листопада 2016 р. Полтава : ПолтНТУ імені Юрія Кондратюка, 2016. C. $157-160$

3. Мелега К. Сучасні технології здоров'язбереження : навчальний посібник. Ужгород : Вид-во УжНУ «Говерла», 2018. С. 56-66.

4. Милославський Д. Сучасні погляди на роль і місце лікувально-профрілактичної дієтетики при захворюваннях внутрішніх органів. Український терапевтичний журнал. 2016. № 3. С. 83-92.

5. Філь М., Свістак Д. Дикоростучі рослини в харчуванні людини. Сучасні аспекти збереження здоров'я людини : збірник наукових праць IX Міжнародної міждисциплінарної науково-практичної конореренції, 22-23 квітня 2016 р. Ужгород. С. 166-168.

6. Міхеєнко О. Особиста відповідальність за стан свого здоров'я як стратегічний принцип оздоровчої практики / за заг. ред. Ю. Бойчука. Загальна теорія здоров'я та здоров'язбереження : колективна монограсрія. Харків : вид. Рожко С.Г., 2017. С. 238-244. 